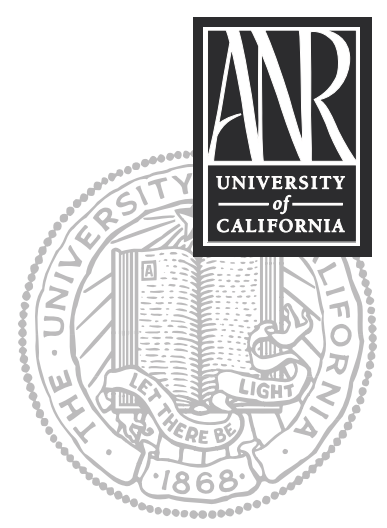

UNIVERSITY OF CALIFORNIA

Division of Agriculture and Natural Resources http://anrcatalog.ucdavis.edu

\title{
Pistachio: Calendar of Operations for Home Gardeners
}

PAMELA M. GEISEL and ROBERT H. BEEDE, University of California Cooperative Extension Farm Advisors, Fresno and Kings Counties

Pistachios can make an excellent nut tree in the home garden in many areas of California. The pistachio nut is a good source of protein, is low in saturated fat, and has no cholesterol. Pistachio trees have few pests, which makes them a good choice for organic gardeners (for more information on pistachio pests, see Pistachio: UC IPM Pest Management Guidelines, available for free downloading from the UC IPM Web site at http://www.ipm.ucdavis.edu/PDF/PMG/pmgpistachio.pdf). Although the availability of faster-growing disease-resistant rootstocks has made home production more feasible, pistachio remains a slow-growing tree, taking 5 to 6 years to produce the first crop of nuts.

Because pistachios are wind-pollinated, bees are not required for nut production, although bees are frequently attracted to the pollen-bearing male flowers. In pistachio, male and female flowers are borne on separate trees; a female tree planted alone will not produce nuts unless a male tree is growing nearby. For best pollination, plant a male upwind of every 10 to 15 female trees. Cultivar choices in pistachios are limited, with most commercial growers planting Kerman as the female tree and Peters as the male tree. The first harvest produces about 5 pounds $(2.3 \mathrm{~kg})$ of split nuts, and the tenth harvest may produce 50 pounds $(23 \mathrm{~kg}$ ) or more. Typically, 20 percent or more of Kerman nuts fail to split, and up to 5 percent have no kernels inside. Pistachio is also alternate bearing, meaning that heavy crops one year are followed lighter crops the next year. Good irrigation and pruning practices can reduce, but not eliminate, alternate bearing.

Pistachios have a high chilling requirement: about 850 hours below $45^{\circ} \mathrm{F}\left(7.2^{\circ} \mathrm{C}\right)$ between November 1 and March 30. Equally important, pistachios require warm, dry weather from July to early September for proper kernel maturation. While the trees tolerate short periods of winter cold to about $27^{\circ} \mathrm{F}\left(-2.8^{\circ} \mathrm{C}\right)$, leaves and flowers can be injured by early fall and spring frosts. Heavy rainfall during pollination can reduce fruit set and cause wet-weather diseases such as Botrytis and Alternaria blights.

Pistachios do best in deep, light- to medium-textured, well-drained soils, but they will grow on many soil types. Pistachios tolerate drought once established, but producing quality kernels with split nuts requires as much as 50 gallons $(190 \mathrm{l})$ of water per tree per day from July to late August in the climate zones where pistachios are grown. However, excessively wet soil promotes root and crown diseases.

\section{WINTER/DORMANT SEASON}

- Plant 1-year-old container-grown trees in January or February.

- Remove broken, dead, and crossing branches and head back shoots (for more information on pruning, see Fruit Trees: Training and Pruning Deciduous Trees, available for free downloading from the ANR CS Web site at http://anrcatalog. ucdavis.edu/pdf/8057.pdf). Pistachios bear fruit from lateral buds on 1-yearold wood. Almost all growth occurs near the terminal end or tip of the branch. Pistachio shoots must be headed back to force lateral growth and keep the canopy upright and compact. As a general rule for heading back branches of mature trees, try to leave two to three vegetative buds beyond the fruit buds at the end of the branch to avoid dieback and provide for next season's growth 
(fruit buds may be distinguished from vegetative buds by size: fruit buds are larger). Heading branches in this manner leaves the branch with 16 to 20 inches (about 40 to $50 \mathrm{~cm}$ ) of last season's growth. Do not prune the shorter branches, which are fruiting spurs. Head back branches on young trees to develop shape and structure. Once trees mature, combine heading cuts with thinning cuts to provide uniform light distribution. Prune with the objective of making the canopy more compact and upright. To reduce alternate bearing, prune more heavily prior to an on-bearing year, even though it causes some crop loss. This improves nut yield during the following off-year.

- Pistachio does not require an annual dormant spray. If soft scale becomes a problem, treat with dormant oil in early to mid-February.

- To reduce the incidence of navel orangeworm during the growing season, gather and destroy all old nuts on the ground and in the tree. This alone can eliminate the need for pesticide use during the growing season.

\section{SPRING/BLOOM SEASON}

- Prune out any disease-blighted shoots and destroy them, particularly if the spring weather is cool and wet during the bloom period. Male Peters trees are susceptible to Botrytis blossom rot in wet weather.

- Remove all weeds and grasses from around the home orchard and around the base of the trees to reduce damage from plant bugs, which are insects with sucking mouthparts that feed on the fruit and damage the pistachio nuts.

- Keep the trunk and crown area around the trunk dry in summer to reduce root and crown rot disease.

- Be careful not to overwater newly planted trees; check the root ball moisture when deciding whether to irrigate. Healthy pistachio trees have reddish tip growth, which, if water stressed, becomes shorter in length. Excessively wet soil causes the foliage to turn slightly yellow. Healthy trees grow about 1 inch $(2.5 \mathrm{~cm})$ per day in warm weather.

- Pistachios frequently suffer from zinc and boron deficiency. Deficiency of either mineral causes poor fruit set and tree growth. Apply a multinutrient foliar spray containing zinc, boron, and copper every 3 weeks on newly planted trees.

- For mature trees, apply zinc as a foliar spray in late October, mid-March, and mid-April. Boron can be added to the mid-March or April treatment.

\section{SUMMER/GROWING SEASON}

- For optimal growth and nut development, keep the soil moist to at least 4 feet $(1.2 \mathrm{~m})$ deep throughout the growing season. By mid-May, a mature pistachio tree consumes 40 gallons (150 l) of water per day in hot, dry climates such as that of California's San Joaquin Valley. From early July to harvest, each tree consumes up to 50 gallons (190 l) of water per day. Pistachios perform very well under low-volume irrigation systems such as minisprinklers or drip. This allows frequent application and reduces water waste from flood or basin irrigation. On newly planted trees, place the emitters within about 1 foot $(30 \mathrm{~cm})$ of the tree base in order to wet the root ball. Each winter, pull the emitter hose such that by the fifth year, the emitters are located halfway between the trees within the row.

- To minimize foliar disease, do not use impact sprinkler heads, which wet the canopy. Monitor soil moisture frequently to determine whether your selected irrigation schedule is keeping up with tree water use. 
- Avoid allowing water to pond on the soil surface for longer than 2 days. The resulting humidity increases the likelihood of Alternaria blight, a foliar disease that causes browning of the leaves and staining of the nut shell just prior to harvest.

- Pistachios have a high nutrient demand during kernel development (July through August). A mature tree requires 5 pounds $(2.3 \mathrm{~kg}$ ) of ammonium sulfate ( 1 pound, or $0.45 \mathrm{~kg}$, of actual nitrogen) during the growing season. Ammonium sulfate is best applied in small amounts from mid-May to early August. As an alternative, apply 20 to 25 pounds ( 9.1 to $11.4 \mathrm{~kg}$ ) of steer manure to each tree per year. Water well after applying fertilizer or manure.

\section{AUTUMN/HARVEST SEASON}

- To minimize damage from navel orangeworm, harvest nuts as early as possible (for more information on harvest and storage, see Harvesting and Storing Your Home Orchard's Nut Crop, available for free downloading from the ANR CS Web site at http://anrcatalog.ucdavis.edu/pdf/8005.pdf). Harvest when the skin (hull) of the nut changes from a greenish to a yellowish-red color. At this stage, the hull readily slips from the nut when squeezed between thumb and index finger, revealing an already split nut. This usually happens in early to mid-September. Do not delay harvest, thinking all the nuts will eventually "slip" or be split. Delaying harvest results in excessive hull tissue breakdown, which causes shell staining and increased insect damage. Also, a certain percentage of nuts remain closed or blank inside no matter how long harvest is delayed. Delaying harvest also promotes losses from birds: a single bird can consume 1 pound $(0.45 \mathrm{~kg})$ of nuts per day.

- Nuts can be shaken or knocked off the tree with a pole onto tarps placed beneath the tree. Do not knock the nuts directly onto the soil, since dirt and contamination from injurious molds can occur.

- Pistachios must be hulled and dried within 24 hours of harvest to avoid staining the shells and initiating Rhizopus species (bread mold) fungal growth. First, place the hulled pistachios in a large bucket of water to float off the "blank" (kernel-less) nuts. Hull the nuts using a large piece of grate-like metal fastened to a frame of $2 \times 4$ lumber. This creates a coarse surface that facilitates hull removal. Wearing thick gloves, rub your hands over the nuts on the grate until most of them have separated from their hulls. In a certain percentage of the nuts, the hull will "stick tight" to the shell, and further hulling increases the percentage of clean nuts only slightly. Also, sticktight nuts are usually poorly filled kernels or blanks. Large quantities of pistachios are best hulled using a commercial potato peeler, which consists of a motor-driven spinning drum with rough sides. Up to 20 pounds $(9 \mathrm{~kg}$ ) of fresh nuts can be hulled at one time.

- After hulling, place the nuts on a clean surface in a warm $\left(75^{\circ}\right.$ to $80^{\circ} \mathrm{F}$, or about $24^{\circ}$ to $26.5^{\circ} \mathrm{C}$ ) well-ventilated area to dry. Layer no more than two nuts deep and cover with bird netting to prevent birds from taking nuts. The nuts should dry in 3 to 4 days under warm conditions. Protect the nuts from rain to avoid spoilage. Nuts hulled with a commercial potato peeler are wetter initially and require warmer drying conditions to prevent molds from developing. Nuts can also be dried in a household oven at $140^{\circ}$ to $160^{\circ} \mathrm{F}$ (about $60^{\circ}$ to $70^{\circ} \mathrm{C}$ ) for 10 to 14 hours. Stir them occasionally to promote even drying. Hulled nuts can be soaked in a brine solution and then roasted for "salted nuts in the shell."

- After harvest, remove and destroy nuts left on the tree as well as those on the ground to reduce injury to the kernels from the pistachio seed chalcid. 
- Freeze the nuts for a few days to kill any insect eggs that may have been present, then store in-shell nuts in a cool, dry place in sealed plastic bags. Shelled nuts may be stored for several months to a year in a refrigerator or freezer. In general, the storage life for shelled nuts is shorter at room temperature than in a refrigerator or freezer.

\section{FOR FURTHER INFORMATION}

You'll find more information on pistachios in the following ANR Communication Services publications:

Fruit Trees: Training and Pruning Deciduous Trees, Publication 8057, 2002, available for free downloading from the ANR CS Web site at http://anrcatalog.ucdavis.edu/pdf/8057.pdf.

Harvesting and Storing Your Home Orchard's Nut Crop, Publication 8005, 1998, available for free downloading from the ANR CS Web site at http://anrcatalog.ucdavis.edu/pdf/8005.pdf.

Pistachio: UC IPM Pest Management Guidelines, Publication 3461, 2004, available for free downloading from the UC IPM Web site at http://www.ipm.ucdavis.edu/PDF/PMG/pmgpistachio.pdf.

To order or obtain printed publications and other products, visit the ANR

Communication Services online catalog at http://anrcatalog.ucdavis.edu. You can also place orders by mail, phone, or FAX, or request a printed catalog of our products from:

University of California

Agriculture and Natural Resources

Communication Services

6701 San Pablo Avenue, 2nd Floor

Oakland, California 94608-1239

Telephone: (800) 994-8849 or (510) 642-2431, FAX: (510) 643-5470

E-mail inquiries: danrcs@ucdavis.edu

An electronic version of this publication is available on the ANR Communication Services Web site at http://anrcatalog.ucdavis.edu.

Publication 8147

ISBN 978-1-60107-318-1

(C) 2004 by the Regents of the University of California, Division of Agriculture and Natural Resources. All rights reserved.

The University of California prohibits discrimination or harassment of any person on the basis of race, color, national origin, religion, sex, gender identity, pregnancy (including childbirth, and medical conditions related to pregnancy or childbirth), physical or mental disability, medical condition (cancer-related or genetic characteristics), ancestry, marital status, age, sexual orientation, citizenship, or status as a covered veteran (covered veterans are special disabled veterans, recently separated veterans, Vietnam era veterans, or any other veterans who served on active duty during a war or in a campaign or expedition for which a campaign badge has been authorized) in any of its programs or activities. University policy is intended to be consistent with the provisions of applicable State and Federal laws.

Inquiries regarding the University's nondiscrimination policies may be directed to the Affirmative Action/Staff Personnel Services Director, University of California, Agriculture and Natural Resources, 300 Lakeside Drive, 6 ${ }^{\text {th }}$ Floor, Oakland, CA 94612-3550, (510) 987-0096. For information about obtaining this publication, call (800) 994-8849. For downloading information, call (530) 754-5112.

pr-10/04-SB/CR

This publication has been anonymously peer reviewed for technical accuracy by University of California scientists and other qualified professionals. This review process was managed by the ANR Associate Editor for Pomology, Viticulture, and Subtropical Horticulture. 


\section{WARNING ON THE USE OF CHEMICALS}

Pesticides are poisonous. Always read and carefully follow all precautions and safety recommendations given on the container label. Store all chemicals in their original labeled containers in a locked cabinet or shed, away from foods or feeds, and out of the reach of children, unauthorized persons, pets, and livestock.

Confine pesticides to the property being treated. Avoid drift onto neighboring properties or gardens containing fruits and/or vegetables ready to be picked.

Dispose of empty containers carefully. Follow label instructions for disposal. Never reuse the containers. Make sure empty containers are not accessible to children or animals. Never dispose of containers where they may contaminate water supplies or natural waterways. Do not pour down sink or toilet. Consult your county agricultural commissioner for correct ways of disposing of excess pesticides. Never burn pesticide containers.

PHYTOTOXICITY: Certain chemicals may cause plant injury if used at the wrong stage of plant development or when temperatures are too high. Injury may also result from excessive amounts or the wrong formulation or from mixing incompatible materials. Inert ingredients, such as wetters, spreaders, emulsifiers, diluents, and solvents, can cause plant injury. Since formulations are often changed by manufacturers, it is possible that plant injury may occur, even though no injury was noted in previous seasons. 